\title{
En mann i 30-årene med residiverende oppkast og magesmerter lindret av varm dusj
}

\author{
Magesmerter, kvalme og oppkast er en vanlig årsak til innleggelse \\ i medisinsk avdeling. Hos vår pasient med residiverende plager ga \\ anamnesen mistanke om en lite kjent tilstand.
}

a

Engelsk oversettelse av hele artikkelen på www.tidsskriftet.no

\author{
Øystein Brenna \\ oystein.brenna@stolav.no \\ Avdeling for fordøyelses- og leversykdommer \\ Knut Aasarød \\ Avdeling for nyresykdommer \\ Medisinsk klinikk \\ St. Olavs hospital \\ Bjørn Inge Gustafsson \\ Avdeling for fordøyelses- og leversykdommer \\ Medisinsk klinikk \\ St. Olavs hospital \\ og
}

Norges teknisk-naturvitenskapelige universitet

En mann i 30-årene ble innlagt i medisinsk avdeling med kvalme, brekninger, oppkast og magesmerter. Han hadde sju år tidligere vært innlagt med stikkende retrosternale smerter med forverring ved inntak av mat og drikke. Den gang fikk han påvist et et lite hiatushernie på $1-2 \mathrm{~cm}$ og en liten injeksjon ned mot Z-linjen. I løpet av de neste årene hadde pasienten flere innleggelser med tilsvarende symptomer. Under den siste innleggelsen kom det frem at han røykte hasj en gang $i$ uken. Ved undersøkelse i mottakelsen hadde pasienten epigastriesmerter, han svettet, var kvalm og kastet opp grønn væske. Han var mager. Blodtrykket ble målt til 140/90 mm Hg, pulsen var 48 og temperaturen målt i øret $35,4^{\circ} \mathrm{C}$. Han var lett palpasjonsøm i epigastriet. Det var ikke diaré, han hadde hatt normal avføring samme morgen, sa han. Han brukte pantoprazol $40 \mathrm{mg} \times 1$. Pasienten opplyste at han hadde røykt hasj dagen før innleggelsen.

Det ble startet med pantoprazol infusjon. Han hadde metabolsk acidose med baseoverskudd (BE) -9,0 mmol/l $(-3-3 \mathrm{mmol} / \mathrm{ll}$ og laktat 5,1 mmol/l (0,5-2,2 mmol/l), men var ikke sirkulatorisk påvirket. Blodprøver viste hemoglobin 17,7 g/100 ml (13,4-17,0 $\mathrm{g} / 100 \mathrm{ml}$, leukocytter $12,9 \cdot 10^{9} / \mathrm{l}(3,7-10,0$. $\left.10^{9} / \mathrm{l}\right)$, kalium $4,9 \mathrm{mmol} / \mathrm{l}(3,5-4,4 \mathrm{mmol} / \mathrm{l})$ og glukose 8,4 mmol/l (4,2-6,3 $\mathrm{mmol} / \mathrm{l})$. Serum-etanol var negativ. Øvrige blodprøver viste ingen signifikante avvik.

Etter at blodprøvene forelå, ble pasienten undersøkt igjen på sengeposten. Han var svært motorisk urolig, svettet, var kvalm, brakk seg og hadde magesmerter. Like etter tok han en dusj. Etter dusjen var han helt upåvirket og i god allmenntilstand, og klinisk undersøkelse var normal. Han innrømmet nå at han hadde røykt hasj daglig i en uke forut for innleggelsen, men benektet inntak av andre rusmidler enn hasj, heller ikke alkohol. Videre kunne han fortelle at han ble mye bedre av å sitte $i$ dusjen, og at han ved liknende symptomer kunne dusje $i$ 4-5 timer daglig. Ikke lenge etter at pasienten hadde dusjet på avdelingen, kom symptomene tilbake. Smerte- og kvalmestillende hadde liten effekt.

På grunn av metabolsk acidose ble urinen undersøkt med tanke på ketoner, og osmolalitets- og aniongap ble kalkulert. Ketoner i urin var positiv. Man mistenkte at ketonurien skyldtes mangelfull ernæring. Det var normalt osmolalitetsgap, men det var et aniongap på 20,1 , som ble tilskrevet forhøyet nivå av laktat og ketoner. Bakgrunnen for laktatforhøyelsen var uavklart, men den kunne kanskje skyldes muskulære rykninger/muskelaktivitet. Porfyriner, porfobilinogen og $\delta$-aminolevulinsyre $\mathrm{i}$ urinen ble analysert, men resultatene forelå først etter utskrivning og var normale.

Symptombildet ble intuiivt tolket som sannsynlig rusrelatert. Vi var usikre på om det kunne stemme med vanlig abstinens, da pasienten var bradykard, selv om dette også kunne skyldes økt vagotoni i forbindelse med oppkast. Ved et søk på Google med «cannabis» og «hyperemesis» fant vi at det tidligere er beskrevet cannabinoid hyperemesis som lindres ved kompulsiv bading (1).

Da tilstanden likevel fortsatt ble betraktet som uavklart, ble han undersøkt med CT abdomen/bekken knapt åtte timer etter innkomst, med tanke på tarmobstruksjon, iskemisk tarm eller andre årsaker til akutte magesmerter og oppkast. Undersøkelsen var normal. Blodgass tatt drøyt 12 timer etter innkomst viste en normalisering av $\mathrm{pH}$ og laktat, men fortsatt litt lavt baseoverskudd og lett hypokapni, men normal oksygenering. Magesmertene, kvalmen og brekningene var gradvis avtakende under innleggelsen. To dager etter at han ble lagt inn, var pasienten mye bedre og ville ha permisjon over helgen. Videre ble han fem dager etter innleggelsen gastroskopert, med normale funn. Da han ble utskrevet, var han mye bedre, men fortsatt $\mathrm{kvalm}$. Han ble informert om at vi mistenkte cannabinoid hyperemesis. Vi anbefalte ham å slutte å røyke hasj.

Man har i ettertid, over ett år etter at han var innlagt, vært i kontakt med ham på telefon flere ganger. Han har ikke klart å slutte med hasj, men oppgir at konsumet er betydelig redusert. Han har ikke hatt tilbakefall av symptomene. I telefonsamtalene kunne han fortelle at han har røykt hasj daglig i 16-17 år. I perioder har han isolert seg hjemme og røykt hasj og drukket kaffe, og matinntaket har vært minimalt. Han beskrev symptombildet på nytt - kvalme og oppkast, magesmerter med følelsen av at innvollene vrenger seg, ofte ledsaget av svettetokter og symptomlindring ved varm dusj. Han benektet polydipsi. I periodene forut for og under perioder med symptomer har han ikke forsøkt å minske hasjrøykingen.

\section{Diskusjon}

Cannabis er en fellesbetegnelse for rusmidler, f.eks. hasj og marihuana, laget av planten Cannabis sativa eller hamp. Den aktive substansen i cannabinoider fra C. sativa er $\Delta^{9}$-tetrahydrocannabinol ( $\Delta^{9}$-THC). $\Delta^{9}$-THC binder seg til to membranreseptorer, $\mathrm{CB}_{1}$ og $\mathrm{CB}_{2}$. $\mathrm{CB}_{1}$-reseptorene er lokalisert i sentrale og perifere nevroner, også i det enteriske nervesystem i fordøyelseskanalen, $\mathrm{CB}_{2}$-reseptorene er involvert $\mathrm{i}$ immunfunksjoner og uttrykkes i plasmaceller og makrofager, men finnes også i områder av hjernen forbundet med emesis (2).

Virkninger av cannabis hos mennesket er humørforandringer (eufori og dysfori), svekket oppmerksomhet, forstyrret oppfatningsevne, kognitive og psykomotoriske forandringer, takykardi og konjunktival injeksjon. Noen effekter av cannabinoider kan være nyttige som medisinsk behandling, for eksempel antiemetiske og analgetiske effekter.

Cannabinoid hyperemesis-syndrom ble først beskrevet i 2004, da man etter kliniske observasjoner ville undersøke sammenhengen mellom kronisk cannabismisbruk og syklisk oppkast (3). Vi har funnet 24 artikler med kasuistikker og kasuistikksamlinger som omhandler cannabinoid hyperemesissyndrom - 13 av disse er fra 2009-10. Det manifeste symptombildet er ofte forutgått av 
en lengre prodromalperiode med kvalme, oppkast og gjerne vekttap. I forløpet oppstår så hyperemesis ledsaget av kvalme, svetting, kolikkaktige magesmerter og polydipsi. Videre observeres en spesiell tillært badeatferd - symptomene lindres i løpet av få minutter ved hjelp av et varmt bad eller en dusj. Hospitalisering skjer som regel når varmtvannet tar slutt eller ved sterk kroppslig svekkelse på grunn av oppkast. Oppkastingen er intraktabel og refraktær for antiemetisk medikasjon (3).

Tilstanden blir bedre etter 24-48 timer med intravenøs væsketerapi, men varer av og til i flere dager (4). Syndromet ses ved kronisk, daglig og betydelig misbruk over flere år (gjerne cannabisbruk i 10-20 år) og kan således være doseavhengig $(3,5,6)$. Insidensen av cannabinoid hyperemesis er ukjent. I en kasuistikksamling av SorianoCo og medarbeidere fra William Beaumont Hospital i Michigan, USA, med 1065 senger og ca. 60000 innleggelser per år, refereres åtte diagnostiserte tilfeller i løpet av åtte måneder (5). Symptomene oppgis å være kronisk tilbakevendende, med nye anfall etter uker til måneder ved vedvarende cannabisbruk. Eneste kjente behandling er å slutte med stoffet. Sontineni og medarbeidere har foreslått kriterier for den kliniske diagnosen ved cannabinoid hyperemesis-syndrom (ramme 1) (7). Grunnen til at syndromet først ble kjent i 2004, kan skyldes økt tilgjengelighet og høyere globalt forbruk i de senere år samt at cannabisen er blitt sterkere, med høyere nivå av $\Delta^{9}$-THC (6).

Hvorfor enkelte cannabismisbrukere utvikler syndromet og andre som røyker like mye av stoffet over like lang tid ikke får symptomer, er uvisst. Det er ikke holdepunkter for å anta at syndromet skyldes blandingsmisbruk, da dette er undersøkt med toksikologiske screeningtester i andre publiserte kasuistikksamlinger. Likevel er det en svakhet at vi verken undersøkte urinen på cannabinoider eller andre rusmidler. Dette ble ikke gjort fordi pasienten allerede hadde innrømmet hasjrøyking og benektet inntak av andre rusmidler. $\Delta^{9}$-THC skilles ut som $\Delta^{9}$-THC-syre, som ved kronisk cannabismisbruk kan påvises $i$ urinen $i$ flere uker etter siste inntak (8). Urinanalyse kan åpenbart være nyttig dersom man står overfor en pasient med liknende symptombilde som benekter rusmisbruk.

Byrne og medarbeidere har uttrykt skepsis mot syndromet (9). Izzo \& Camillieri argumenterte i 2008 for at tilstanden skyldes cannabisabstinens (2). Det er solid dokumentasjon for at det eksisterer et cannabisabstinenssyndrom (10). Cannabisabstinens foreslås nå inkludert i Diagnostic and Statistical Manual of Mental Disorders (DSM)-5. Imidlertid hadde ingen av pasientene $\mathrm{i}$ den opprinnelige beskrivelsen av cannabinoid hyperemesis-syndrom hatt ønske om eller forsøkt å slutte med cannabis før de ble syke, snarere tvert imot (3). Dette var også tilfellet hos vår pasient.

Mekanismen ved syndromet er ukjent. Cannabinoider har lang halveringstid, er lipofile og binder seg i cerebralt fett, og regelmessig bruk kan føre til akkumulering og toksisitet (3). Videre kan cannabis påvirke hypothalamus via $\mathrm{CB}_{1}$-reseptorer og forstyrre den normale termoreguleringen $(1,3)$. $\Delta^{9}$-THC fører til doseavhengig hypotermi hos mus (11). Ikke i noen av kasuistikkene der kroppstemperaturen er angitt, har den vært påfallende lav eller høy. Vår pasient hadde en øretemperatur på $35,4{ }^{\circ} \mathrm{C}$ og har forklart at han i perioder med symptomer hadde økt svette og frysninger. Siden inntak av cannabis tradisjonelt har vært assosiert med antiemetisk virkning, er syndromet tilsynelatende et paradoks - imidlertid kan noen pasienter som får cannabis som kvalmestillende eller appetittstimulerende, oppleve kvalme, oppkast og magesmerter (1).

Det mest karakteristiske ved syndromet er kanskje badeatferden. Det er ikke kjent hvorfor varme bad lindrer symptomene. Ulike forklaringsmodeller er lansert for å forklare dette. Chang \& Windish forsøker å forklare dette med at hjernen reagerer på nedsatt kjernetemperatur på grunn av den hypoterme virkningen av cannabis eller at pasienten etterstreber høyere hudtemperatur på grunn av direkte virkning av $\Delta^{9}$-THC på $\mathrm{CB}_{1}$-reseptorer i hypothalamus og at dette ikke nødvendigvis er en respons på nedsatt kjernetemperatur (1). Patterson og medarbeidere mener at $\mathrm{CB}_{1}$-mediert vasodilatasjon $\mathrm{i}$ splanchnicusgebetet bidrar til symptomene og at varm dusj fører til en redistribusjon av blod til huden og dermed lindrer (12).

Det er også vist at cannabinoidreseptoragonister forsinker ventrikkeltømming og intestinal transitt (2). Dette kan også forklare noen av symptomene. Det ble ikke beskrevet ventrikkelretensjon ved gastroskopiene hos vår pasient.

I en oversiktsartikkel av Darmani diskuteres andre mulige forklaring på syndromet. Cannabis inneholder 60 stoffer med cannabinoid struktur, slik at det kan være ett eller flere av disse, og ikke $\Delta^{9}$-THC, som forårsaker oppkast. I tillegg kan genetiske forskjeller i cytokrom P-450-systemet føre til økt opphopning av cannabinoide metabolitter som kan føre til oppkast hos enkelte individer. Videre kan det være slik at $\Delta^{9}$-THC har en paradoks bifasisk emetisk/antiemetisk effekt ved at det kan opptre både som partiell agonist og som antagonist. Kronisk cannabiseksponering kan også føre til desensibilisering og reduksjon $\mathrm{i}$ reseptortettheten, som kan true endocannabinoidreseptorinhiberingen, med økt tilbøyelighet til oppkast som følge. Noen individer kan være ekstra sensitive for den stimulerende effekten av $\Delta^{9}$-THC på frigjøring av endocannabinoider og inflammatoriske substanser, for eksempel arakidonsyre, som kan virke proemetiske (13).

\section{Ramme 1}

Foreslåtte kriterier for cannabinoid hyperemesis-syndrom (7)

- Essensielt for diagnosen

- Regelmessig cannabisbruk i flere år

- Kliniske hovedtrekk ved syndromet

- Betydelig kvalme og oppkast

- Oppkast i syklisk mønster over måneder

- Bedring av symptomene etter opphør av cannabisbruk

- Tilleggsmomenter - Symptomlindring ved kompulsiv bading/dusjing i varmt vann

- Kolikkpregede magesmerter

- Ingen tegn på kolecystitt eller pankreatitt

Kort fortalt: Cannabinoid hyperemesissyndrom et relativt nylig beskrevet klinisk bilde med ukjent patogenese. Enkelte har satt spørsmålstegn ved om de observerte kliniske trekk som omfattes av dette syndromet skyldes cannabisbruk. Tilstanden kan være underdiagnostisert og kan også bli hyppigere i fremtiden, i og med at cannabismisbruket har økt i Norge. Klinikere bør derfor kjenne til tilstanden, og man bør overveie muligheten for cannabinoid hyperemesis og ta opp rusanamnese ved utredning av pasienter med (syklisk) oppkast og magesmerter av ukjent årsak. Ved å kjenne til syndromet kan man unngå omfattende utredning og gjentakelse av de samme undersøkelsene gang på gang. Kasuistikken illustrerer også nytten av raskt tilgjengelig medisinsk informasjon via Internett ved uklare og ukjente symptombilder (14).

Pasienten har gitt tillatelse til at artikkelen blir publisert.

\section{Øystein Brenna (f. 1975)}

er assistentlege ved Medisinsk klinikk, Avdeling for fordøyelses- og leversykdommer. Ingen oppgitte interessekonflikter.

\section{Knut Aasarød (f. 1950)}

er dr.med. og avdelingsoverlege ved Avdeling for nyresykdommer

Ingen oppgitte interessekonflikter.

\section{Bjørn I. Gustafsson (f. 1965)}

er dr.med. og overlege ved Avdeling for fordøyelsessykdommer. Han er forsker ved Institutt for kreftforskning og molekylærbiologi og leder for Norsk gastroenterologisk forening.

Ingen oppgitte interessekonflikter. 


\section{Litteratur}

1. Chang YH, Windish DM. Cannabinoid hyperemesis relieved by compulsive bathing. Mayo Clin Proc 2009; 84: 76-8

2. Izzo AA, Camilleri M. Emerging role of cannabinoids in gastrointestinal and liver diseases: basic and clinical aspects. Gut 2008; 57: 1140-55.

3. Allen JH, de Moore GM, Heddle R et al. Cannabinoid hyperemesis: cyclical hyperemesis in association with chronic cannabis abuse. Gut 2004: 53: 1566-70.

4. Sullivan S. Cannabinoid hyperemesis. Can J Gastroenterol 2010; 24: 284-5.

5. Soriano-Co M, Batke M, Cappell MS. The cannabis hyperemesis syndrome characterized by persistent nausea and vomiting, abdominal pain, and compulsive bathing associated with chronic marijuana use: a report of eight cases in the United States. Dig Dis Sci 2010; 55: 3113-9.

6. Wild K, Wilson H. Cannabinoid hyperemesis. BMJ Case Reports 2010; doi: 10.1136/bcr.01.2010.2605

7. Sontineni SP, Chaudhary S, Sontineni V et al.

Cannabinoid hyperemesis syndrome: clinical diagnosis of an underrecognised manifestation of chronic cannabis abuse. World J Gastroenterol 2009; 15: 1264-6.

8. Khiabani HZ, Mørland J. Cannabis og cannabinoider som legemidler. Tidsskr Nor Lægeforen 2007; 127: 579-82.

9. Byrne A, Hallinan R, Wodak A. «Cannabis hyperemesis» causation questioned. Gut 2006; 55: 132.

10. Ashton $\mathrm{CH}$. Pharmacology and effects of cannabis: a brief review. Br J Psychiatry 2001: 178: 101-6.

11. Hayakawa K, Mishima K, Hazekawa M et al. Cannabidiol potentiates pharmacological effects of Delta(9)-tetrahydrocannabinol via CB(1) receptordependent mechanism. Brain Res 2008; 1188 . 157-64.

12. Patterson DA, Smith E, Monahan M et al. Cannabinoid hyperemesis and compulsive bathing: a case series and paradoxical pathophysiological explanation. J Am Board Fam Med 2010; 23: 790-3.

13. Darmani NA. Cannabinoid-induced hyperemesis: a conundrum - from clinical recognition to basic science mechanisms. Pharmaceuticals 2010; 3: 2163-77.

14. Greenwald R. ... And a diagnostic test was performed. N Engl J Med 2005; 353: 2089-90.

Mottatt 9.9. 2010, første revisjon innsendt 17.11. 2010 godkjent 17.3. 2011. Medisinsk redaktør Lars Frich. 